University of Michigan Law School

University of Michigan Law School Scholarship Repository

\title{
Hardening of the Attitudes: Americans' Views on the Death Penalty
}

Phoebe C. Ellsworth

University of Michigan Law School, pce@umich.edu

Samuel R. Gross

University of Michigan Law School, srgross@umich.edu

Available at: https://repository.law.umich.edu/articles/594

Follow this and additional works at: https://repository.law.umich.edu/articles

Part of the Constitutional Law Commons, Criminal Law Commons, and the Law and Psychology

Commons

\section{Recommended Citation}

Gross, Samuel R., co-author. "Hardening of the Attitudes: Americans' Views on the Death Penalty." P. C. Ellsworth, co-author. J. Soc. Issues 50, no. 2 (1994): 19-52.

This Article is brought to you for free and open access by the Faculty Scholarship at University of Michigan Law School Scholarship Repository. It has been accepted for inclusion in Articles by an authorized administrator of University of Michigan Law School Scholarship Repository. For more information, please contact mlaw.repository@umich.edu. 


\title{
Hardening of the Attitudes: Americans' Views on the Death Penalty
}

\author{
Phoebe C. Ellsworth and Samuel R. Gross \\ University of Michigan
}

American support for the death penalty has steadily increased since 1966, when opponents outnumbered supporters, and now in the mid-1990s is at a near record high. Research over the last 20 years has tended to confirm the hypothesis that most people's death penalty attitudes (pro or con) are based on emotion rather than information or rational argument. People feel strongly about the death penalty, know little about it, and feel no need to know more. Factual information (e.g., about deterrence and discrimination) is generally irrelevant to people's attitudes, and they are aware that this is so. Support for the death penalty has risen for most major felonies. Youth is seen as much less of a mitigating factor than it was 35 years ago, but most people still oppose the execution of the mentally retarded. As crime rates have risen despite repeated promises by politicians to "get tough on crime," the death penalty has become an increasingly prominent issue in electoral politics, suggesting that public opinion should be an issue of central importance for research. We suggest that future research should focus more explicitly on racial attitudes, on comparisons of the death penalty with specific alternatives, and on the emotional aspects of attitudes toward the death penalty.

The best known fact about American attitudes toward capital punishment is that support for the death penalty as at a near record high. Figure 1 graphically displays this familiar fact in a familiar historical context; it is further documented

This research was supported by the Cook Funds of the University of Michigan Law School. We are grateful to Ian Kremer and Matthew Perez for their assistance in tracking down articles and survey data, to Barbara Brown for her ability to do excellent work preparing both manuscript and graphs at the usual short notice, and to Marcea Metzler for her assistance with the appendix and the figures. Donald Kinder, Sheldon Levy, and Hugo Bedau provided helpful suggestions at various stages of our writing.

Correspondence regarding this article should be sent to Phoebe C. Ellsworth, 5242 Institute for Social Research, University of Michigan, Ann Arbor, MI, 48106, or to Samuel R. Gross, Law School, University of Michigan, Ann Arbor, MI 48109. 


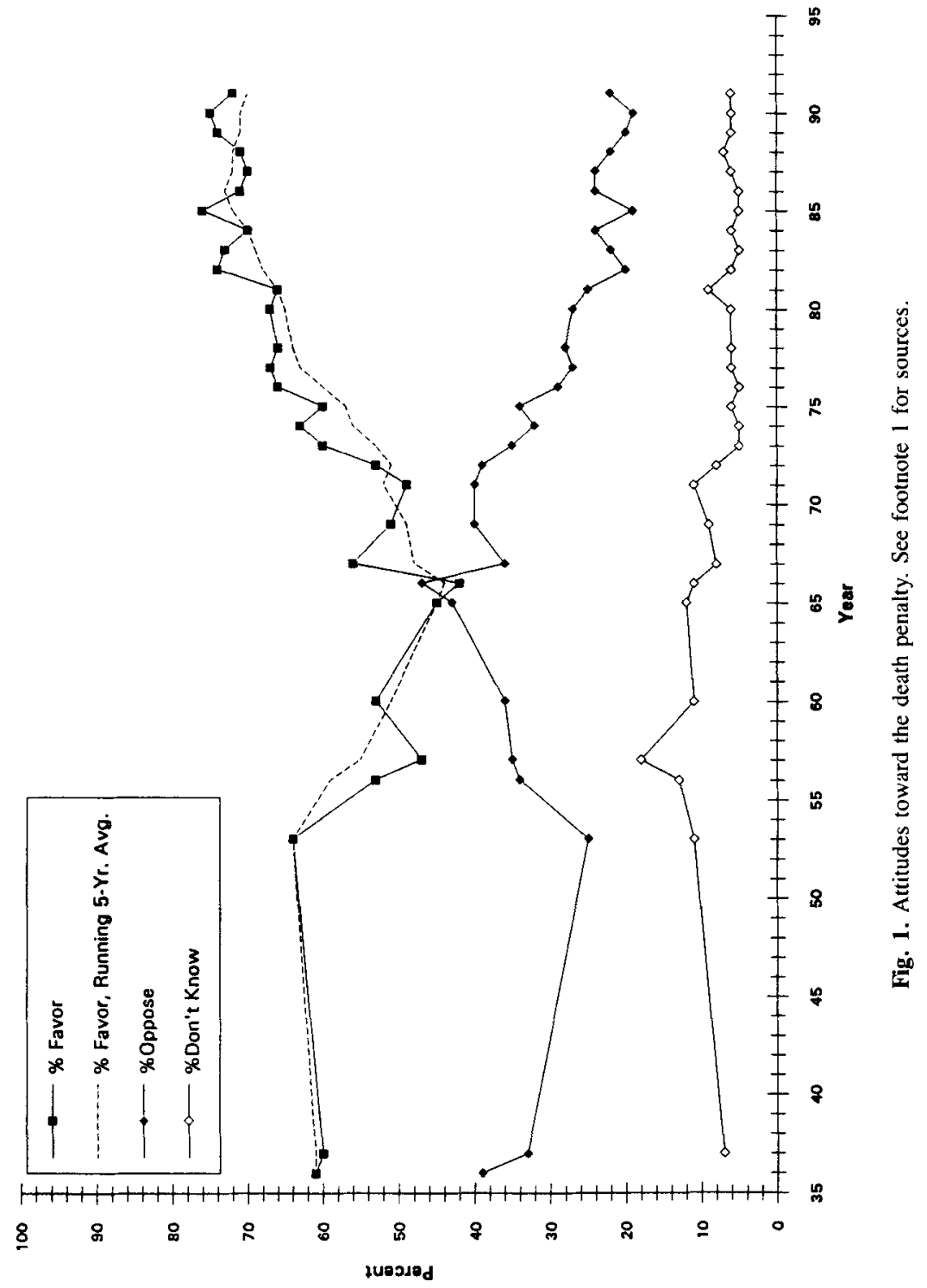


in the Appendix. As measured by public opinion polls, support for capital punishment declined through the 1950 s to a low of $47 \%$ in 1966; increased steadily from 1966 through about 1982; and has remained roughly stable since 1982, in the range of $70 \%-75 \% .^{1}$

Figure 2 shows two other well-known facts about American public opinion on the death penalty: Throughout the entire period for which poll data are available, men have favored the death penalty more than women, and Whites have favored it more than Blacks. Other smaller correlations have frequently been found: Republicans favor the death penalty more than Democrats, conservatives more than liberals, the middle class more than the poor, Westerners more than Easterners and Midwesterners, suburbanites more than city and country dwellers (Bohm, 1991; Erskine, 1970; Fox, Radelet, \& Bonsteel, 1991; Smith, 1976; Zeisel \& Gallup, 1989). These demographic variables, however, are weak predictors. For example, in a logistic regression model including all of these variables plus several others, Fox et al. (1991) were able to predict only $8 \%$ of the variance in general death penalty opinions on NORC surveys from 1972 through 1988.

Several writers have discussed the limitations of the single-question pro/con format typically used in general population surveys of death penalty attitudes (P. W. Harris, 1986; Vidmar \& Ellsworth, 1974; Wallace, 1989). Answers to this kind of question tell us little about what people think or feel or notice-why they support or oppose capital punishment, what they know about it, how and to whom they believe it should be applied, how this attitude is related to their behavior or to other attitudes-the issues to which the bulk of this article is devoted. ${ }^{2}$ Still, these soundings of general opinion are important.

First, the legal status of the death penalty in the United States depends on

'The time line displayed in Fig. 1 is based on data from polls by the Gallup organization for 1936-1971 and for 1981, and on data from the NORC's General Social Surveys (GSS) for 1972-78, for 1980, and for 1982-1991. These choices reflect competing considerations. The General Social Survey is the best periodic national opinion poll available, but Gallup has the longest history of conducting national surveys that include questions on capital punishment. Therefore, we have used GSS data when possible, and Gallup data otherwise. These are not, of course, the only national polls on general attitudes toward the death penalty. A computerized data base that is publicly available from the Roper Center for Public Opinion Research at the University of Connecticut included 90 such surveys as of July 1993. The Appendix includes a list of all these surveys, the text of the questions asked, and the proportions of respondents giving each coded answer. Unless otherwise attributed, the polls we refer to in the text are taken from the Roper data base, which can be accessed through LEXIS or WESTLAW, and will be referred to simply by survey organization and the month and year in which the survey was completed (e.g., "Gallup, 10/74"). In general, we focus on national surveys, and refer to local and regional studies to the extent that they cover ground not covered by the national polls.

2Two limitations on the scope of this article are appropriate at this point. We do not discuss the issue of death penalty attitudes and jury selection in capital cases, commonly known as "death qualification" (see Ellsworth, 1988), and we do not discuss the personality correlates of death penalty attitudes. 


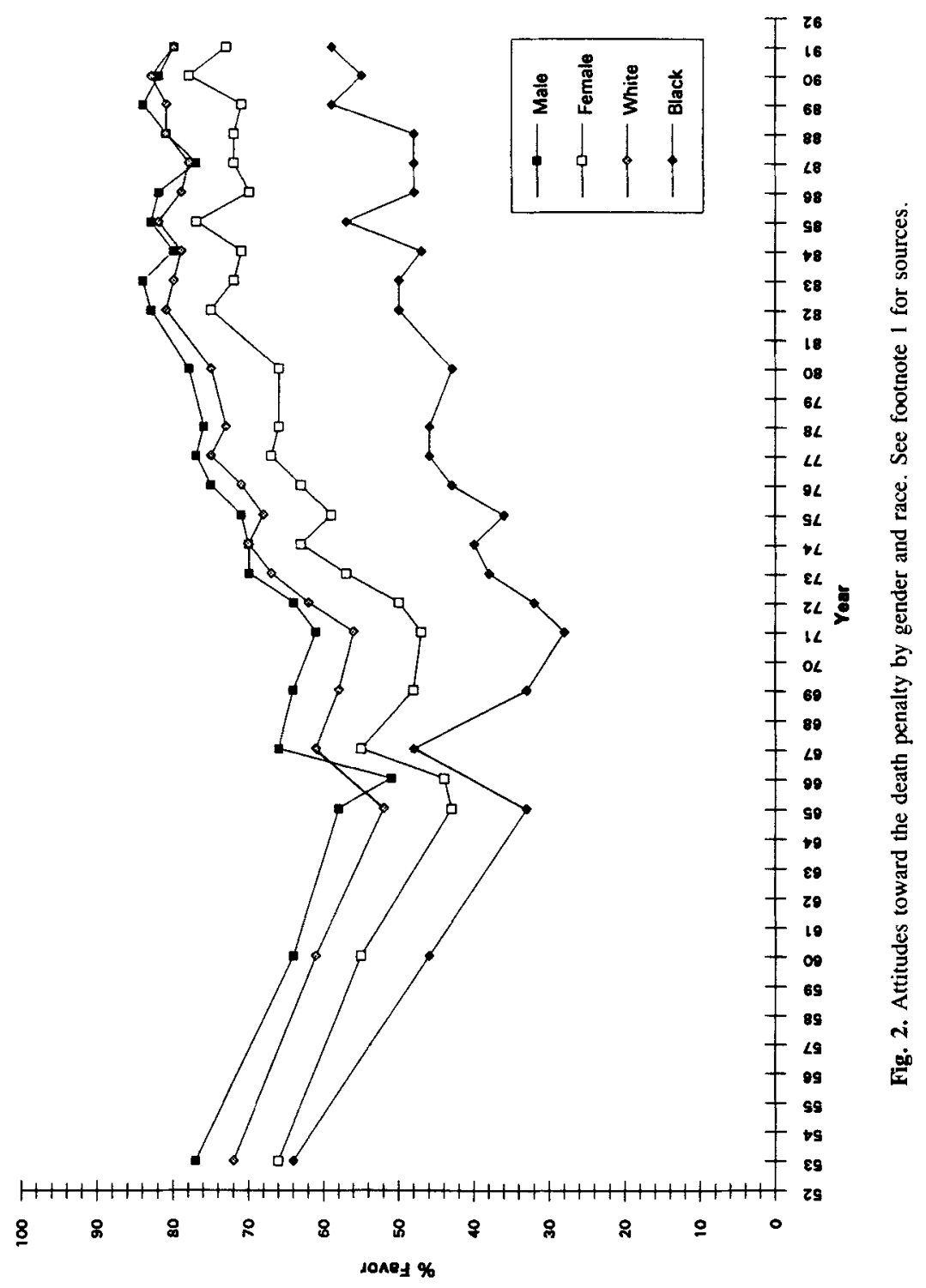


popular support, actual and perceived. In 1972, when the Supreme Court first addressed the claim that the death penalty is a "cruel and unusual punishment" and therefore unconstitutional, all of the justices agreed that the legality of capital punishment depends on its acceptability under contemporary standards (Furman v. Georgia, 1972). The Court has maintained this position ever since, although various justices have disagreed about the value of opinion polls (as opposed to jury behavior and legislative enactments) as a source of information on "contemporary standards." In 1972-with public opinion on capital punishment fairly evenly split, but support on the rise-the Supreme Court's decision in Furman left the legal status of the death penalty in doubt. The Court held that all existing death sentences in the country were unconstitutional because they had been imposed under systems that permitted the "arbitrary" use of capital punishment, but it deferred a decision on the constitutionality of the death penalty as such. Four years later, when the Court revisited the issue and decided that capital punishment is constitutional (Gregg v. Georgia, 1976), the public was unmistakably pro-death penalty - as the polls revealed-and it has remained so ever since.

In the long run, popular support may not be sufficient to guarantee the retention of the death penalty. As Zimring and Hawkins (1986) have pointed out, in the past 30 years capital punishment has been abolished in West Germany, Great Britain, Canada, and France, despite majority support. The same could happen in the United States, although not likely soon. On the other hand, popular support may well be necessary to the continued use of the death penalty in this country. If a clear majority comes to reject this form of punishment, we predict that the Supreme Court, if not Congress and the state legislatures, will soon follow suit.

Second, general opinions about the death penalty are subjectively important to many, perhaps most, people in this society. For example, in November 1986, 65\% of the respondents in an Associated Press/Media General poll of the national adult population said that the death penalty is an issue they "feel very strongly about." This may not surprise anybody who watches TV news or reads newspapers in America. But it is surprising to learn that on an ABC News exit poll of 23,000 voters in the 1988 presidential election, $27 \%$ checked "the candidates' positions on the death penalty" as an issue that was "very important" to them in choosing between George Bush and Michael Dukakis. The only item that scored higher was abortion (33\%); the presidential debates and the candidates' stands on illegal drugs were close behind ( $26 \%$ each); the candidates' political parties scored $23 \%$; and their positions on matters such as education ( $22 \%$ ), health care (21\%), and social security (19\%) all trailed.

Perhaps capital punishment is so important to people because it has become a point on which people do not so much form opinions as choose sides: $I$ am for the death penalty, George Bush is for the death penalty, Michael Dukakis is 
against the death penalty. To the extent that this is true, the critical step is selfidentification as a supporter or an opponent of capital punishment-and general opinion questions, however vague, may be perfectly suited to determine that identification. Indeed, the patterns of answers to these questions offer some slight evidence that death penalty attitudes are a matter of self-identification.

Inevitably, the precise distribution of responses to death penalty questions varies from survey to survey even within short periods of time. Most such differences are in the range from $1 \%$ to $5 \%$, and are easily explained by random sampling error, and by the multitude of possible problems in the design and implementation of mass surveys. What is more striking, from our point of view, is the absence of systematic differences between the results of competing polls that phrase their questions about capital punishment differently. The usual question asked on the General Social Survey (GSS) is, "Do you favor or oppose the death penalty for persons convicted of murder?" Before 1981, the usual Gallup question was, "Are you in favor of the death penalty for persons convicted of murder?" Harris polls generally ask, "Do you believe in capital punishment (the death penalty) or are you opposed?" None of the differences between these formats, or among the half-dozen other questions that we have grouped together in Appendix 1 under the heading "Standard Question," has any noticeable impact on the answers. Consider, for example, the results of three polls conducted in 1976: GSS, 4/76-Favor 66\%, Oppose 30\%, Don't know 5\%; Gallup, 4/76Yes $66 \%$, No $26 \%$, No opinion $7 \%$; Harris, 12/76-Favor 67\%; Oppose 25\%; Not sure $8 \%$.

Experiments using different forms of survey questions have shown that some variations in wording are likely to matter much more than others. For example, formal balance ("favor or oppose" vs. "favor") usually makes little difference (Schuman \& Presser, 1981, pp. 180-184). By contrast, providing a context for the opinion ("If [another] situation like Vietnam were to develop," should the United States "send troops" vs. should the United States "send troops to stop a communist takeover") often changes the results by a substantial margin (Schuman \& Presser, 1981, pp. 275-296)—but on this issue it makes no difference. Indeed, the distribution of responses remains roughly unchanged even when aggravated categories of death-worthy crimes are mentioned. Compare, for example, the 12/82 Yankelovitch survey question ("Wider use of the death penalty for such crimes as hijacking or killing a police officer"- $73 \%$ favor) to the standard question on the $4 / 83$ GSS survey ( $73 \%$ favor). Nor does it seem to make much of a difference if a popular justification for the death penalty is spelled out. For example, the 6/84 AP/Media General survey asked, "Various proposals have been made as possible solutions to the increased crime rate. Please tell me whether you personally favor or oppose the following measures to reduce the crime rate . . ." The death penalty alternative got about the same level of "Favor" responses $(69 \%)$ as the death penalty questions on a 1/84 Roper survey, which referred to ". . serious crimes such as murder, 
kidnapping, etc." (68\%), and the 4/84 GSS (70\%), which asked the standard question.

The form of endorsement of the death penalty that is offered also appears to make little difference. It can be "Are there any crimes for which the death penalty is justified?" (CBS/NYT, 7/77, 7/88, 4/89), or "Do you favor or oppose . . bringing back the death penalty?" (Yankelovitch, 9/83, 12/83, 9/84), and the levels of support are close to those obtained with general attitude questions. It does not matter if the respondents are asked whether they would vote for a proposition favoring the death penalty (Gallup, 10/74, 9/82); nor-despite large acquiescence response bias effects in other contexts (Schuman \& Presser, 1981, pp. 203-230)does it matter if they are required to state that they would vote to oppose "Amending the constitution to outlaw the death penalty" (NBC/Wall Street Journal, 12/91). The only changes in question format that seem to have predictable effects on levels of support are those that deal with the frequency of death sentences. On the one hand, questions that ask whether the respondents favor a mandatory death penalty produce substantially lower support; for example, compare the $12 / 81$ Gallup survey ( $54 \%$ favor mandatory death penalty) to the $4 / 82$ GSS (74\% generally favor death penalty). On the other hand, some surveys ask whether, among "persons convicted of first degree murder," the death penalty should be given to "all," "no one," or whether it "should depend on the circumstances of the case and the character of the person." If we interpret the answer "no one" as opposition to capital punishment, and "all" and "depends" as support, these questions produce a sizable pro-death penalty shift; for example, compare the 4/73 Harris survey "All" + "Depends" $=81 \%$ ) to the $4 / 73$ GSS (60\% general support for capital punishment).

It seems that most Americans know whether they "favor" or "oppose" the death penalty, and say so in response to any question that can reasonably be interpreted as addressing that issue. This conclusion is reinforced by evidence that the form of the response categories has little effect on overall levels of expressed support for capital punishment. Several surveys have allowed respondents to say that they favor or oppose the death penalty "strongly" or "somewhat" (L.A. Times, 4/81, 7/86, 3/89), or "very strongly" and "not too strongly" (Gallup, 1/86). The total proportions on each side of the neutral point are consistent with roughly contemporaneous surveys that offered only two choices. In addition, three Los Angeles Times surveys (3/85, 7/86, 3/89) offered the choice "I haven't heard enough about that to say." Similar manipulations have been shown to have dramatic consequences in related contexts. For example, Schuman and Presser (1981, p. 120) describe an experiment on the 1974 GSS in which the following question was asked to a split sample in two forms, with and without the italicized portion: "In general, do you think the courts in this area deal too harshly or not harshly enough with criminals, or don't you have enough information about the courts to say?" In the first form $6.8 \%$ volunteered that they didn't know; in the second $29 \%$ chose "Not enough information to say." By compari- 
son, only $4 \%$ of the respondents in the 1989 Los Angeles Times survey said that they "hadn't heard enough" to express an opinion on the death penalty (an additional $9 \%$ said they were not sure or refused to answer), and only $2 \%$ said so on the other two surveys that offered this option.

\section{Expressed Reasons for Death Penalty Attitudes}

Before 1970, almost no one thought to ask survey respondents why they favored or opposed the death penalty. Since then several researchers have attempted to do so; their general conclusion is that simply asking people about the reasons for their attitudes is not an effective means of discovering those reasons. Ellsworth and Ross (1983), for example, found that respondents tended to endorse all "reasons" that were consistent with their basic position. If they favored capital punishment, they agreed with almost all the reasons for support; if they opposed capital punishment, they agreed with almost all the reasons for opposition. Ellsworth and Ross concluded that most people's attitudes toward capital punishment are basically emotional. The "reasons" are determined by the attitude, not the reverse.

Even though it now seems naive to think we can discover the reasons for people's attitudes toward capital punishment simply by asking direct questions, an examination of people's expressed reasons can still be illuminating. Overall levels of support for the death penalty are far higher than they were in 1973, executions have resumed, thousands of people are now on death row, and there have been conspicuous cases of innocent people narrowly escaping execution. Do people give the same reasons for their attitudes as they did 20 years ago?

There are two basic methods for asking people about reasons for their death penalty attitudes. The first is to provide a list of possible reasons for supporting or opposing the death penalty and to ask respondents which ones they agree with. The second, less common, is simply to ask the open-ended question, "Why do you favor (or oppose) capital punishment?" The first method is susceptible to the problem discovered by Ellsworth and Ross (1983): Any reason on the list that supports one's basic attitude is likely to be endorsed, and the only way to differentiate among them is to look at relative strength of endorsement. The second method is potentially much more useful, as it does not suggest reasons to respondents that they had not previously entertained. However, people are often unaware of the bases for their attitudes, and if they have not thought much about why they favor or oppose the death penalty they may not be able to give valid answers (Nisbett \& Wilson, 1977).

\section{Deterrence and Retribution}

Twenty years ago the reason most commonly given for supporting the death penalty was that it was a deterrent to crime (Thomas, 1977; Thomas \& Foster, 
1975; Vidmar, 1974; Vidmar \& Ellsworth, 1974). At that time the deterrent effectiveness of the death penaity was a hotly debated issue, and surveys of death penalty attitudes began to include questions about belief in deterrence. Thus, unlike other rationales for the death penalty, we have two decades of comparable data on belief in deterrence. The top portion of Fig. 3 shows the percent of people supporting the death penalty, and the percent of people agreeing that the death penalty is a deterrent to murder (or crime, the wording varies slightly from one poll to the next) in surveys of nationwide random samples of adults from 1972 to 1991 . Only polls that offered two alternatives, rather than scales of belief strength, are presented, for the sake of comparability.

It is clear that the marked increase in support for the death penalty is not due to a growing belief that the death penalty is a deterrent to murder. Belief in the deterrent efficacy of the death penalty hovers around $60 \%$ for most of the 19 -year period, while support for the death penalty rises from $58 \%$ to $75 \%$. Indeed, a number of recent polls indicate that people believe other measures, such as job training and drug rehabilitation programs, are more effective than capital punishment in reducing crime (Bowers, 1993; Bowers \& Vandiver, 1991a,b).

Proponents of capital punishment, of course, are far more likely than opponents to agree that the death penalty is a more effective deterrent than life imprisonment. In their 1974 survey of California Bay Area residents, Ellsworth and Ross (1983) found that $93 \%$ of proponents agreed that "the death penalty is a more effective deterrent than life imprisonment," while $92 \%$ of opponents disagreed, and many other polls have found that belief in deterrence is highly correlated with support for the death penalty. However, in their attempt to find out whether people's belief in deterrence was a fundamental reason for people's death penalty attitudes, Ellsworth and Ross (1983) asked people whether their basic position on the death penalty would change if it could be proven that they were wrong about its deterrent efficacy. They found that most proponents would still favor the death penalty if life imprisonment were an equally effective deterrent, and most opponents would still oppose it even if it were a "much more effective" deterrent than life imprisonment. The same hypothetical question was added to the Gallup Poll in 1985, with very similar results. Proponents would still favor the death penalty if it "does not lower the murder rate" (72\%, 73\%, and $69 \%$ in 1985,1986 , and 1991 , respectively), and opponents would still oppose it if it were a deterrent $(67 \%, 71 \%, 65 \%$; Gallup News Service, 1991). Thus current public opinion poll data continue to support the conclusion that people's attitudes about the death penalty are not determined by their beliefs in its deterrent effectiveness.

The other major reason for favoring the death penalty is retribution. Commentators in the early 1970s (Thomas \& Foster, 1975; Vidmar \& Ellsworth, 1974) argued that an expressed belief in deterrence was a more socially acceptable, "legitimate" rationale for supporting the death penalty than the more emotional, possibly vengeful motive of retribution, and thus was more likely to be a 


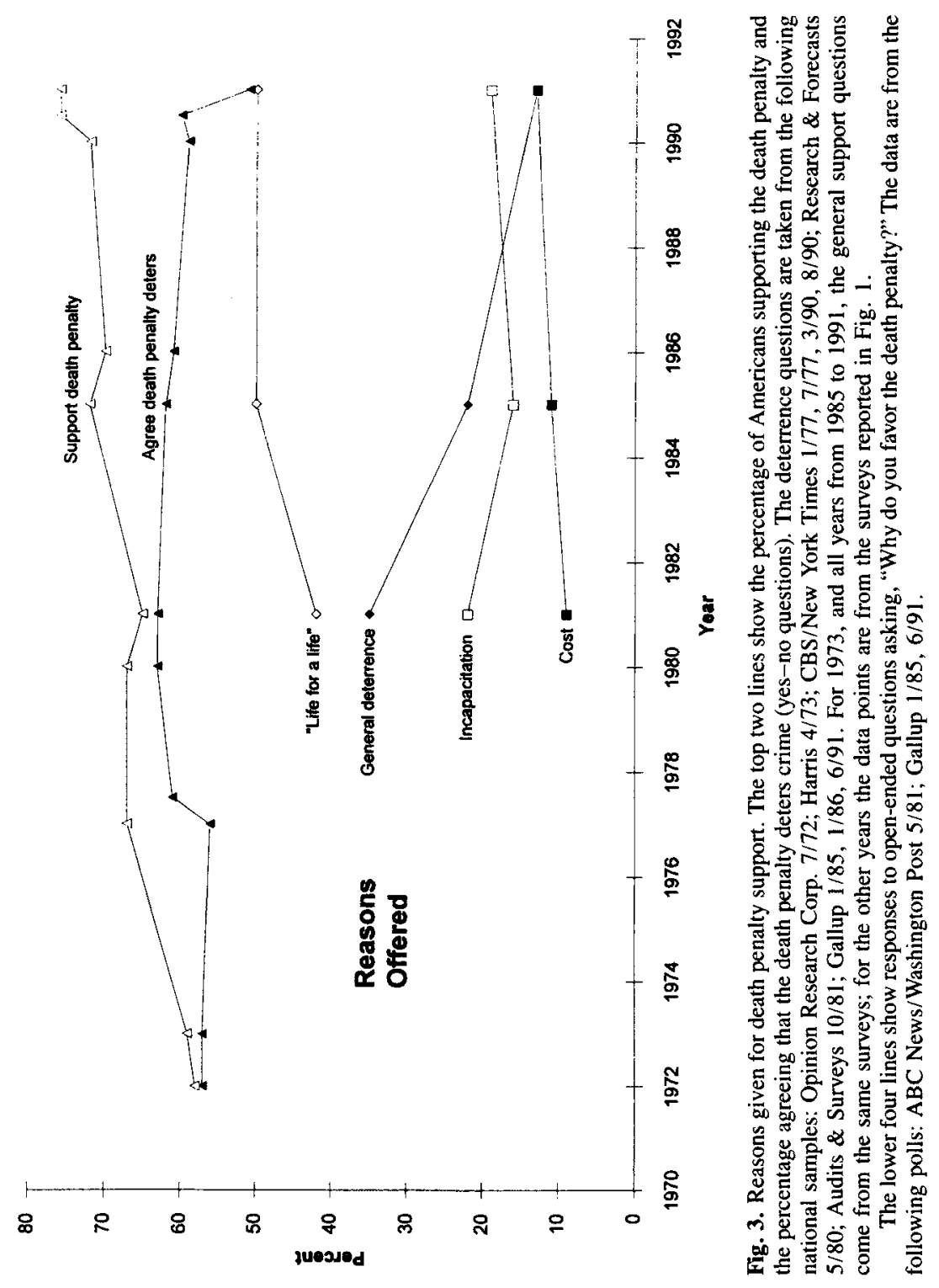


reason people were willing to offer to pollsters. Several scholars have suggested that the norms of social desirability have changed, and that retribution is now an acceptable reason for favoring the death penalty (Fox et al., 1991; Haney, Hurtado, \& Vega, 1993; P. W. Harris, 1986; Warr \& Stafford, 1984). As support for the death penalty has increased, so has willingness to endorse retribution as a motive.

The measurement of people's belief in retribution is much more problematic than the measurement of their death penalty attitudes or their belief in deterrence. We have seen that changes in question wording have little effect on general levels of support for the death penalty, and the same is true for belief in deterrence. For example, the 1980 and 1981 polls reported in Fig. 3 were conducted by two different organizations (Research \& Forecasts, 5/80; Audits \& Surveys, 10/81). The first asked, "Does the death penalty discourage murder?" The second asked, "Do you believe that capital punishment-the death penalty-is or is not a deterrent to crime?" In both cases $63 \%$ of the population expressed a belief in deterrence. Harris (4/73) found the same level of belief in the deterrent superiority of capital punishment over life imprisonment, regardless of whether "life imprisonment" included parole as an option. Retribution questions, on the other hand, can be phrased in terms of a principled belief in justice, a merciless passion of revenge, or anywhere in between. Very few researchers have used agreedisagree retribution questions comparable to the deterrence questions, and every survey phrases the question differently. Not surprisingly, endorsement of items designed to tap retributive sentiments ranges from quite low (when words like "revenge" are used) to quite high. The variation due to question wording makes it impossible to tell if there has been any long-term trend.

Since 1980 there have been three national random-sample polls that asked open-ended questions about respondents' reasons for supporting or opposing the death penalty (ABC News/Washington Post, 5/81; Gallup 1985 and 1991, reported in Gallup Poll News Service, July 26, 1991). The lower graph on Fig. 3 presents these data. Retribution ("a life for a life") has been a more popular reason than belief in deterrence since 1981 . It is possible that people were more reluctant to express retributive motives a decade earlier, but we have no comparable data. Support for the law of talion has increased over the past 10 years, but far more striking is the marked decrease in the proportion of people who spontaneously give general deterrence as their reason (see also Warr \& Stafford, 1984). Retribution is by far the most common reason given for favoring the death penalty.

\section{Cost}

Figure 3 shows a slight upward trend in people's willingness to mention the cost of keeping a person in prison. When we developed our list of possible justifications for the death penalty in 1973 (Ellsworth \& Ross, 1983), we interviewed death penalty supporters in depth to try to make sure we covered the 
range of possible reasons. No one mentioned the high cost of prison, and we did not include it. Apparently discussing human lives in monetary terms was even more unacceptable than believing in revenge $(45 \%$ of proponents we sampled agreed that "society has a right to get revenge when a very serious crime like murder has been committed"). People have become less hesitant to mention cost spontaneously (Gallup Poll News Service, 1991), and when cost is explicitly included as an alternative, a substantial minority of proponents endorse it. In 1986 P. W. Harris found that $38 \%$ of those who favored a death penalty in all circumstances and $21 \%$ of those who favored it in some circumstances endorsed "the high cost of imprisonment" as one of their reasons. If this is a genuine basis for supporting the death penalty, it is a misguided one; the available evidence suggests that the death penalty is far more expensive than life imprisonment (Cook \& Slawson, 1993; Costanzo \& White, this issue; Dieter, 1992).

\section{Incapacitation}

Finally, Fig. 3 indicates that only $20 \%$ or fewer respondents give incapacitation-keeping a particular killer from killing again-as a reason for favoring the death penalty, and there is no clear trend over the decade. However, a series of recent studies aimed at discovering whether there are any alternatives to capital punishment that would satisfy the public (Bowers, 1993; Bowers \& Vandiver, 1991a, 1991b; Dieter, 1993) suggests that incapacitation may be more important to people than their responses have indicated.

We have argued, as have many others (Ellsworth \& Ross, 1983; P. W. Harris, 1986; Tyler \& Weber, 1982; Wallace, 1989), that death penalty attitudes are an aspect of people's ideological self-definition, and that they are strongly held. Bowers (1993) argues that the apparent strength of people's commitment to capital punishment may be due to the fact that survey questions rarely allow them to compare it with any alternative; either no alternative is given or "life imprisonment" is presented without further specification. Twenty years ago it made no difference whether "life imprisonment" or "life imprisonment without parole" was included as the alternative to the death penalty (Harris, 4/73), but there are reasons to believe times have changed. First, an increasing number of studies indicates that most people, including jurors in capital cases (Bowers, 1993; Dieter, 1993) do not believe "life imprisonment" means anything of the sort. In a recent study, only $4 \%$ of respondents believed murderers sentenced to life actually spend their whole lives in jail; the average estimate of a "life sentence" was 15.6 years (Costanzo \& Costanzo, 1994; Dieter, 1993). In states where the only alternative to the death penalty is life without parole, few citizens realize that this is so (Dieter, 1993). (In California, the state does not leave these impressions to chance. The jury in a capital case is instructed by the judge that "a Governor may in the future commute or modify a sentence of life imprisonment without the possibility of parole to ... include the possibility of parole." [California $v$. 
Ramos, 1982].) Second, Willie Horton and other high-publicity cases have made the image of the released prisoner who immediately commits new atrocities highly available to the public.

Bowers asks respondents, "If convicted murderers in this state could be sentenced to life in prison with absolutely no chance of ever being released on parole or returning to society, would you prefer this as an alternative to the death penalty?" In all five states (California, Florida, Georgia, Nebraska, New York) where this question has been asked, more people have preferred this form of life imprisonment (Bowers, 1993). Adding a requirement that the murderer "be required to work in prison industries for money that would go to the families of their victims" further diminishes support for the death penalty. Dieter (1993) replicated these results in a national poll.

Both incapacitation and retribution probably play a role in people's willingness to endorse these alternatives. People want to be absolutely sure that vicious murderers never ever have a chance to victimize anyone else (outside of prison), and they do not believe "life imprisonment" currently provides that sort of guarantee. But they also want to be sure the murderer never ever has a chance to live a normal life, because he does not deserve to. The addition of a commitment to contribute to the victim's family adds a further element of retribution-in the form of restitution-and undercuts the argument that death is the only punishment that could recompense the surviving victims.

There are problems with demand characteristics in Bowers' work. The question wording is very strong, and the alternatives to the death penalty are arranged in a sequence of severity from "parole after 25 years" to "parole after 40 years" to "absolutely no chance of parole" to "no chance of parole" plus restitution. Also, we must remember that (as on all contemporary surveys) strong majorities in each of these states do support the death penalty under the conditions that they believe actually prevail. In that context, it's hard to say what these results mean. Would anything short of death convince most Americans that there is really no chance that a prisoner will ever return to society? Is the popularity of real "life without parole" best understood as a qualification on popular support for the death penalty, or as an expression of cynicism about the prison system? Despite these problems, this is the first new approach to studying attitudes toward capital punishment in many years, and the first approach that has suggested that there might be substantial flexibility on the part of those who favor the death penalty.

\section{Emotions}

Many commentators have argued that death penalty attitudes are not based on rational considerations at all, but are fundamentally noninstrumental symbolic attitudes, based on emotions and ideological self-image (Ellsworth \& Ross, 1983; Gorecki, 1983; P. W. Harris, 1986; Tyler \& Weber, 1982; Wallace, 1989). Oddly enough, despite the popularity of this idea, hardly anyone has asked 
respondents questions that give them the opportunity to express their emotions directly, and some have intentionally confined their response alternatives to those that are rational (P. W. Harris, 1986). Perhaps researchers have feared that respondents might be reluctant to express emotional bases for their attitudes, but this fear may be groundless. Ellsworth and Ross (1983), for example, found that $79 \%$ of these who favored the death penalty said that they had sometimes "felt a sense of personal outrage when a convicted murderer was sentenced to a penalty less than death," and 34\% said that the death of a murderer could give them "a sense of personal satisfaction." In any case, we will not find out unless we ask. Emotions are becoming a legitimate topic in the study of other political attitudes (Kinder, 1994), and we would hope to see the emotional correlates of death penalty attitudes studied directly, rather than being inferred from the failure of nonemotional beliefs to be very informative.

\section{Reasons for Opposing Capital Punishment}

Many fewer polls have asked why the opponents oppose capital punishment. This may be partly because by the time survey researchers started asking detailed questions about reasons, the proponents were a clear majority, so their views were more relevant to public policy. It may be because the clash between utilitarian reasons (deterrence, cost) and reasons based on values (retribution) is less salient.

Just as most proponents say they would still favor the death penalty if it had no deterrent effect, most opponents would still oppose it even if it were an effective deterrent $(61 \%, 71 \%$, and $65 \%$ in 1985,1986 , and 1991 , respectively; Gallup Poll News Service, 1991). Thus, like the attitudes of the proponents, attitudes of most opponents are very strong, and not based on utilitarian considerations. They are willing to sacrifice lives to avoid having a death penalty. On the other hand, saying that they would be unmoved by evidence of superior deterrence does not reflect any inconsistency: When asked why they oppose the death penalty, opponents rarely refer to its failure as a deterrent. In response to openended questions in surveys over the last 10 years, only $5 \%-10 \%$ of opponents mentioned deterrence. Other "utilitarian" reasons, such as the unfair application of the penalty, the risk of executing innocent people, or the possibility of rehabilitation, are also very infrequently mentioned as reasons for opposition.

People oppose the death penalty because they think it is wrong. In 1981, 1985, and 1991 (ABC/Washington Post, 5/81; Gallup Poll News Service, 1991) the most commonly given "reason" has been that it is "wrong to take a life" (or the slightly more ambiguously coded "taking a life solves nothing"), and the proportion of opponents giving this opinion has held steady at about $40 \%$. The next most popular reason is basically that same reason with an explicitly religious rationale, e.g., "punishment should be left to God." 
People favor the death penalty because they think killing is wrong: "a life for a life" is the most popular reason spontaneously given for supporting it. For both proponents and opponents, their preferred rationale is moral and absolute; they are taking a stand that brooks no argument and suggests little differentiation. Such attitudes are unlikely to be swayed by arguments based on factual information.

\section{Knowledge and Beliefs}

In his concurring opinion in Furman v. Georgia (1972), Justice Thurgood Marshall argued that popular support for the death penalty was based on ignorance. There are two parts to this famous hypothesis: (1) The American public is generally unaware of several unhappy "facts" about capital punishment - that it does not deter homicide more than long terms of imprisonment, that its operation is inhumane, that its administration is discriminatory, that convicted murderers are rarely executed, and that they pose little future threat to society (pp. 364 365). (2) If these "facts" were well known, "the great mass of citizens . . would conclude that the death penalty is immoral and therefore unconstitutional" (p. 363). Virtually all the published studies on the relationship between death penalty attitudes and factual knowledge were conducted in response to this Marshall Hypothesis; the two best, within three years after Furman.

Sarat and Vidmar (1976) interviewed 181 residents of Amherst, Massachusetts, in 1975. Most of their respondents knew that capital punishment is rarely imposed and that it is subject to discrimination by wealth (59\% on each item), but few knew that "studies have shown" that it does not deter homicide (36\% and $22 \%$, depending on the form of the question). They conclude that the first step in the Marshall Hypothesis is supported in part: their respondents were reasonably well informed on the use of the death penalty, but ill informed on its effects. Ellsworth and Ross (1983) provide more detailed data on a survey of 500 northern Californians in 1974, which also revealed widespread ignorance. Most respondents, from $54 \%$ to $89 \%$, did not know that most Western European countries had abolished capital punishment, that comparisons across time and jurisdiction fail to show that the death penalty deters, that it is more costly than life imprisonment, and so forth. In general, opponents of the death penalty were more likely to answer correctly, but, as the authors note, this does not necessarily mean that they were better informed. It is also possible that the two groups were equally ignorant, but each tended to agree with the items supporting their position. This would create a bias, since on most of the items the correct answer was consistent with the anti-death penalty position. In addition, supporters and opponents were in general agreement on several issues. Majorities in both camps (62\% and $81 \%$, respectively) agreed correctly on the discrimination item, and pluralities agreed incorrectly on relative cost and abolition in Europe. The only 
strong differences were on several items related to deterrence and on a related item concerning the average length of time served under a life sentence. ${ }^{3}$

Ellsworth and Ross also found a great deal of uncertainty about the operation and effects of the death penalty. Many respondents happily checked "I have no idea" in response to these questions. On a 5-point scale, this admission of ignorance drew from $25 \%$ to $49 \%$ of the respondents on seven of nine information items, and was the modal response on four. The exceptions were the cost item (16\% said "I have no idea"--but only $11 \%$ answered correctly that capital punishment is not cheaper than life imprisonment) and an item on discrimination by wealth ( $9 \%$ had "no idea," and $68 \%$ correctly said that poor murderers were more likely to be sentenced to death). Both of these questions seem to call for common sense social-economic reasoning; in one case, common sense is probably accurate, in the other it is misleading. Equally striking is the tentativeness with which those respondents who did have an idea answered. On every item, those who said, "I think it's true," outnumbered those who said, "I'm sure it's true," and those who said, "I think it's false," outnumbered those who said, "I'm sure it's false." These comparisons hold for respondents who favor the death penalty, oppose it, or are undecided. In only 1 out of 36 possible comparisons did those who were sure (pro or con) outnumber those in the same group who had tentative thoughts in the same direction.

The second step in Justice Marshall's argument-that if the facts were known, capital punishment would be rejected-is an expression of democratic optimism: knowledge persuades. Unfortunately, the best study on the point is discouraging. Lord, Ross, and Lepper (1979) compared subjects who believed the death penalty deters homicide and subjects who believed it does not. Both groups were given a pair of fictitious studies, one providing data that clearly supported the deterrence hypothesis and the other strongly refuting it. In each group (and regardless of the methodologies of the studies) the subjects accepted the evidence that favored the position they already held, and rejected the contrary evidence. The net effect of reading two balanced but contradictory studies was that prior beliefs were strengthened and preexisting differences were polarized. Similarly, Roberts (1984) found that pro- and anti-death penalty subjects remembered those portions of stimulus literature that supported their positions.

The world, however, does not have the same structure as Lord et al.'s

${ }^{3}$ Ellsworth and Ross (1983) also included the item, "In several cases people executed for murder in the United States were later proven innocent." Supporters of capital punishment were less likely than opponents to agree with this statement, $46 \%$ to $66 \%$, and more likely to reject it, $23 \%$ to $10 \%$. Ellsworth and Ross, in keeping with the accepted wisdom of the time, interpreted the claim as false, and agreement with it as error. More recent research, however, suggests that several people executed for murder in the United States were indeed later proven innocent by reliable means (e.g., a death bed confession of the true criminal) if not in formal judicial proceedings (Radelet, Bedau, \& Putnam, 1992). 
elegant study. Facts about the death penalty are not neatly balanced; as Justice Marshall wrote, on the important factual issues that have been in dispute (deterrence, cost, discrimination, consistency) the truth is on the side of anti-death penalty arguments. Moreover, some citizens (unlike the subjects in this study) have weak opinions on the death penalty, or are entirely undecided. Sarat and Vidmar (1976) examined the effect of information on attitudes by asking their respondents to read one or both of two 1500 word essays containing information about Utilitarian aspects of capital punishment (deterrence and recidivism) and Humanitarian aspects (discrimination and the process of executions); a control group was given an unrelated essay about other legal issues. A posttest of the respondents' death penalty attitudes seemed to support Justice Marshall. The informational essays did produce a shift in the direction of opposition to capital punishment; the Utilitarian essay produced a larger change than the Humanitarian, and the combination was more effective than either separately.

A close review of these findings shows them to be entirely consistent with Lord et al. Sarat and Vidmar measured death penalty attitudes on a 7-point scale, from "very strongly in favor" to "very strongly opposed." In the three experimental conditions, only $4 \%(1 / 24)$ of respondents who favored the death penalty "very strongly" changed their attitude in the expected direction, and only $21 \%$ $(6 / 28)$ of those who favored it "strongly." By comparison, 57\% (34/60) of respondents who were "uncertain" or who favored or opposed the death penalty "somewhat" moved in the direction of opposition. Moreover, only 2 of the 46 respondents whose attitudes changed to any extent $(4 \%)$ moved from any position in support for the death penalty to any level of opposition. All other shifts were changes of intensity within groups (primarily among the less intense) and movement in and out of the undecided group. This suggests that general knowledge of the truths that Justice Marshall wanted to teach the public would have only a modest effect on public opinion. At most, it might increase opposition by about the proportion of people who are undecided-currently around 8\% - and it would probably have little or no impact on those who support the death penalty most strongly.

Recent national poll data are consistent with this conclusion. We have already discussed the data on beliefs about deterrence. In addition, Gallup polls in 1985 and 1991 found that $39 \%$ and $45 \%$ of the respondents, respectively, agreed that Blacks are more likely to be sentenced to death than Whites. On the same polls, $64 \%$ and $60 \%$ agreed that poor defendants were more likely to be sentenced to death than rich defendants. Gallup (Gallup Poll News Service, 1991) also reports that Black respondents were considerably more likely than Whites to agree that these forms of discrimination take place, $73 \%-41 \%$ for race and $72 \%-59 \%$ for poverty. Similarly, on a 11/86 AP/Media General poll, 50\% said that the death penalty "Is not carried out fairly," and only $32 \%$ said that it "Is carried out fairly." Given the overall levels of support for the death penalty since 
1985, the inescapable conclusion is that a large proportion of the American public already believes the death penalty is unfair, but supports it nonetheless.

\section{Who Should be Sentenced to Death?}

\section{Mandatory vs. Discretionary Death Penalty}

When the Supreme Court declared current capital punishment statutes unconstitutional in 1972, it did so on the ground that the discretion allowed to jurors in deciding who should live and who should die was so unlimited that the choice was ultimately arbitrary (Furman v. Georgia, 1972). Some states attempted to remedy this arbitrariness by instituting mandatory capital punishment: everyone convicted of specified categories of murder would automatically be sentenced to death. In 1976 the Supreme Court held that mandatory death penalties are unconstitutional (Woodson v. North Carolina, 1976; Roberts v. Louisiana, 1976). The public apparently shares the view that not everyone who is eligible for the death penalty should get it. Support for a mandatory death penalty is consistently weaker than general support for the death penalty (see above, p. 25), although it too has grown in the recent past. When respondents are given a choice between a mandatory and a discretionary death penalty, they prefer the latter. The Harris poll included this question in $4 / 73,12 / 76,1 / 83$, and Gallup in 7/85. Except for 1976 , when there was only a slight preference for a discretionary death penalty, over $50 \%$ of those polled favored a discretionary death penalty, while fewer than $30 \%$ favored a mandatory death penalty.

Further, some of those who express support for a "mandatory" death penalty do not think that everyone convicted should be executed. Ellsworth and Ross (1983) found that the percentage of people who said that $100 \%$ of those convicted of a given crime should be executed was always lower than the percentage of people who endorsed a "mandatory" death penalty for that crime. In that same survey, some opponents of the death penalty felt the proportion of people who should be executed for a given crime should be greater than zero. It is clear that proponents of mandatory death penalties want the discretion to spare an occasional sympathetic killer, while some opponents of capital punishment want the discretion to execute a few especially villainous ones. Most people prefer a death penalty that allows the decision maker to make distinctions in every case.

Most capital sentencing statutes attempt to codify the important distinctions by providing juries with lists of aggravating factors that might justify a sentence of death, while reminding them that any factor may be considered as a justification for rejecting the death penalty. No national poll has examined people's views of the kinds of considerations that should distinguish between life and death for a given crime, although a few smaller scale surveys have done so (e.g., Haney et al., 1993; Harris, 1986). The national polls have focused primarily on the types 
of crimes that should be punishable by death, and occasionally on the type of criminal.

\section{Which Crimes Should be Punishable by Death?}

Table 1 displays levels of support for the death penalty for selected crimes, based on nationwide surveys using questions of the general form, "Do you favor the death penalty for the crime of X?" Questions allowing the three options "death for all," "death for some," and "death for none" generally show higher levels of support when the "all" and "some" categories are combined. Openended questions ("What do you think should be the penalty for X?") generally show lower levels.

The most obvious conclusion to be drawn from the table is that the rise in general support for the death penalty has been accompanied by an across-theboard rise in support for capital punishment for the various specific crimes.

Table 1. Percent Favoring the Death Penalty for Specific Crimes

\begin{tabular}{|c|c|c|c|c|c|c|c|}
\hline \multirow[b]{2}{*}{ Year } & \multicolumn{7}{|c|}{ Crime } \\
\hline & Murder & Rape & Hijacking & $\begin{array}{l}\text { Kill Police/ } \\
\text { Guard }\end{array}$ & Paid Killing & Terrorism & Child Sex \\
\hline $\begin{array}{l}1972 \\
1973\end{array}$ & $\begin{array}{l}53 \\
60\end{array}$ & & 38 & 60 & & & \\
\hline 1974 & 63 & & & 54 & 58 & & \\
\hline 1975 & 60 & & & & & & \\
\hline 1976 & 66 & & & 52 & 56 & & \\
\hline 1977 & 67 & & & & & 55 & \\
\hline $\begin{array}{l}1978 \\
1979\end{array}$ & 66 & 32 & 37 & & & & \\
\hline 1980 & 57 & & & 58 & 64 & & \\
\hline 1981 & 66 & 37 & 22 & & & & \\
\hline 1982 & 74 & & & & & & \\
\hline 1983 & 73 & & & & & & \\
\hline 1984 & 70 & & & & & & \\
\hline 1985 & 76 & 45 & 45 & & & & \\
\hline 1986 & 71 & 54 & & $\begin{array}{l}62 \text { (Police) } \\
56 \text { (Guard) }\end{array}$ & 74 & 79 & 35 \\
\hline 1987 & 70 & & & & & & \\
\hline 1988 & 71 & 51 & 50 & & & & \\
\hline 1989 & 74 & & & & & & \\
\hline 1990 & 75 & & & & & & \\
\hline
\end{tabular}

Note. The data are from national polls asking yes-no questions of the format, "Do you favor the death penalty for the crime of X?" The sources are as follows: Hijacking-1972 Opinion Research Corp., all other years Gallup; Terrorism-Harris; Rape-1986 Associated Press/Media General, all other years Gallup; Paid killing-1986 Associated Press/Media General, all other years Roper; Child Sexual Molestation-Associated Press/Media General; Killing a policeman or prison guard-1972 Opinion Research Corp.; 1974, 1976, 1980 Roper; 1986 Associated Press/Media General. The sources of the data on Murder are described in footnote 1. 
These trends can also be seen in the percentage of people who favor death as the penalty for crimes not included in the table: arson, robbery, hijacking, or kidnapping in which someone is killed (Roper 3/74, 3/76, 4/80); and assassination of high public officials (Roper, 3/74, 3/76, 4/80; Gallup, 11/85, 9/88). In general death is favored more for the crimes involving killing, although a substantial number of people also favor death for rape, hijacking, and spying.

It also seems that particular crimes are singled out for death when they have attracted public attention. For example, public support for the death penalty for rape and for terrorism has increased much more during the past 15 years than support for the execution of people who kill police officers or prison guards. The feminist movement has clearly affected public consciousness about the seriousness of rape, and terrorism has become a much more salient issue. Salient crimes change with the times. In 1942, in wartime, $85 \%$ of a nationwide sample spontaneously named the death penalty as the appropriate punishment for spies (Gallup, 7/42); since then a majority has always opposed it. In 1986 the sexual molestation of a child became a survey item for the first time, and $35 \%$ of the population favored the death penalty for this crime (AP/Media General, 11/86); it would be wonderful to know what people would have said in 1970 , or 1960 , or 1950 , before the crime was widely publicized.

Another media crime of the late 1980 s and 1990 s is drug dealing. In a 6/51 Gallup poll, in response to an open-ended question, $14 \%$ of Americans said they favored the death penalty for "selling drugs to teenagers." In 1969 only $2 \%$ mentioned the death penalty as a possible punishment for "dope peddling" (Gallup, 1/69); in both years, the plurality favored long prison sentences. Those are the only two national surveys before 1985 to ask about the death penalty for selling drugs. Since then eleven surveys have asked about it, but their questions are so different that support ranges from 1\% (AP/Media General, 11/86) in which only the $40 \%$ who said they favored the death penalty for crimes other than murder were asked about specific crimes, to 73\% (Times Mirror, 5/90), in which $42 \%$ of the population "strongly favored" and $31 \%$ "favored" the death penalty for "drug traffickers." The idea of death for drug dealing is new, and question wordings suggest everything from the little kid who sells cocaine on his block to major drug "kingpins," so it is impossible to say how the public feels on this issue. It is a new issue, a hot issue, the public is uncertain, and question wording makes a big difference. Not enough time has elapsed to observe trends on any particular question.

\section{Which Criminals Should be Punished with Death?}

Three groups-women, young people, and people suffering from mental retardation-have been singled out by survey researchers as possible exceptions to statutes authorizing the death penalty. In $1937,58 \%$ of the population favored 
the death penalty for women, about the same proportion as favored the death penalty in general (Gallup, 12/37). By 1953 the proportion had fallen to $51 \%$ : $75 \%$ of those who favored the death penalty in general $(68 \%)$ also favored it for women (Gallup, 1953). Although women are hardly ever sentenced to death, it appears that there is no overwhelming public sentiment against it; more likely it is because women are much less likely than men to commit capital murder (Rapaport, 1991). Since 1953 the question has not been included on any national survey.

Support for the execution of young people ("under 21 ," "under 18," "teenager") has risen dramatically since 1936, when this question was first asked. In $1936,28 \%$ of Americans were "in favor of the death penalty for persons under 21 " (Gallup, 12/36). By 1953 this proportion had dropped to $19 \%$, and by 1957 it had dropped still further to $11 \%$ (Gallup, 11/53, 9/57). In 1965 it had risen to $21 \%$ (Gallup, 1/65) even though general support for the death penalty was at its lowest. The question was not asked again until 1988 (Harris, 9/88) when 44\% favored the death penalty for persons under 18, and in a 1989 poll (with a considerably smaller sample than the others) $57 \%$ favored the death penalty for 16- and 17-year-olds (Time/CNN/Yankelovich, 6/89). While this last figure may be exaggerated, clearly the former reluctance to execute adolescents has been muted, perhaps because people's current image of a violent killer is an adolescent.

That these two recent polls do not reflect a willingness to execute all murderers is indicated by people's views, on the same two polls, about the execution of "mentally retarded individuals." In 1988 only $21 \%$ of the population favored the death penalty for mentally retarded killers; in 1989 the figure was $27 \%$. This lack of public support for the execution of mentally retarded offenders is particularly noteworthy because it has not been reflected either in practiceseveral retarded people have been executed and many more are awaiting execution-or in law. The Supreme Court held in 1989 that it does not offend public standards of morality to execute a person who was mentally retarded (Penry v. Lynaugh, 492 U.S. 302).

No nationwide survey has asked about aggravating factors other than the type of crime and the demographic characteristics of the criminal. A few more limited-sample surveys provide some data about the kinds of cases that provoke the strongest support for the death penalty, the criminals the public most wants to see executed. Two characteristics stand out: (1) the murder was especially brutal (Haney et al., 1993; Harris, 1986), and (2) more than one person was killed (Ellsworth \& Ross, 1983; Haney et al., 1993; Harris, 1986). Although the data are sparse, it is plausible that these are the killers who come to mind when people are asked about the death penalty - the remorseless, brutal, uncontrollable killer. A few studies have found that people are far more likely to favor the death penalty in the abstract than they are to favor it in specific, concrete cases (Doob 
\& Roberts, 1984; Ellsworth, 1978; Fein \& Lord, 1987), and have raised the hypothesis that this is because most real murderers seem less deviant and horrible than the nightmare vision of a killer that comes to mind when we are asked about capital punishment.

\section{Conclusion}

Support for the death penalty is at an all time high, both in the proportion of Americans who favor capital punishment and in the intensity of their feelings. Most people care a great deal about the death penalty but know little about it, and have no particular desire to know. This is not surprising, as their attitudes are not based on knowledge. Although all justifications consistent with one's position are typically endorsed, those that are offered spontaneously and endorsed most strongly are not the kind that could be easily changed by information. This characterization of death penalty attitudes is based on hypotheses that have been in the literature for nearly 20 years (Ellsworth \& Ross, 1983; Sarat \& Vidmar, 1976); indeed, much of the work of the past 20 years has simply provided empirical support for old hypotheses rather than generating new ideas. In particular, it does not explain why support for the death penalty has steadily increased beyond all previous levels.

In the 1930s and 1940s pollsters rarely asked about the death penalty, probably because it was an accepted and uncontroversial fact of life. (Interestingly, two of the earliest death penalty questions on national polls-Gallup $12 / 36$ and Gallup 11/53 - were asked on the heels of unusual and highly publicized executions: Bruno Hauptmann for the Lindbergh baby kidnap-murder in April 1936, and the Rosenbergs for espionage in June 1953.) In any event, no trend can be inferred from the sketchy data that are available before the 1950s. Since then, however, overall trends in support for the death penalty have been well documented and, at the aggregate level, they seem easy to explain by reference to crime and homicide rates (Page \& Shapiro, 1992, pp. 92-94; Rankin, 1979). The initial period of declining support (1953-1966) occurred at a time when the reported violent crime rate and the homicide rate were both comparatively low; the rapid increase in support that followed (1966-1982) corresponded roughly to a period of rapid increase in both of these indices of criminal violence; and the current pattern of high but stable support (1982-1992) developed in a period of high and reasonably stable violent crime and homicide rates. Figure 4 shows these trends.

This is a simple commonsensical explanation: when crime goes up, people look for harsher punishments to bring it back down. Page and Shapiro report similar changes in the 1960 s and 1970s for other sketchier attitudinal measures of punitiveness, such as the proportion of respondents who felt the courts are "not harsh enough" in their treatment of criminals (1992, pp. 90-93). The actual 


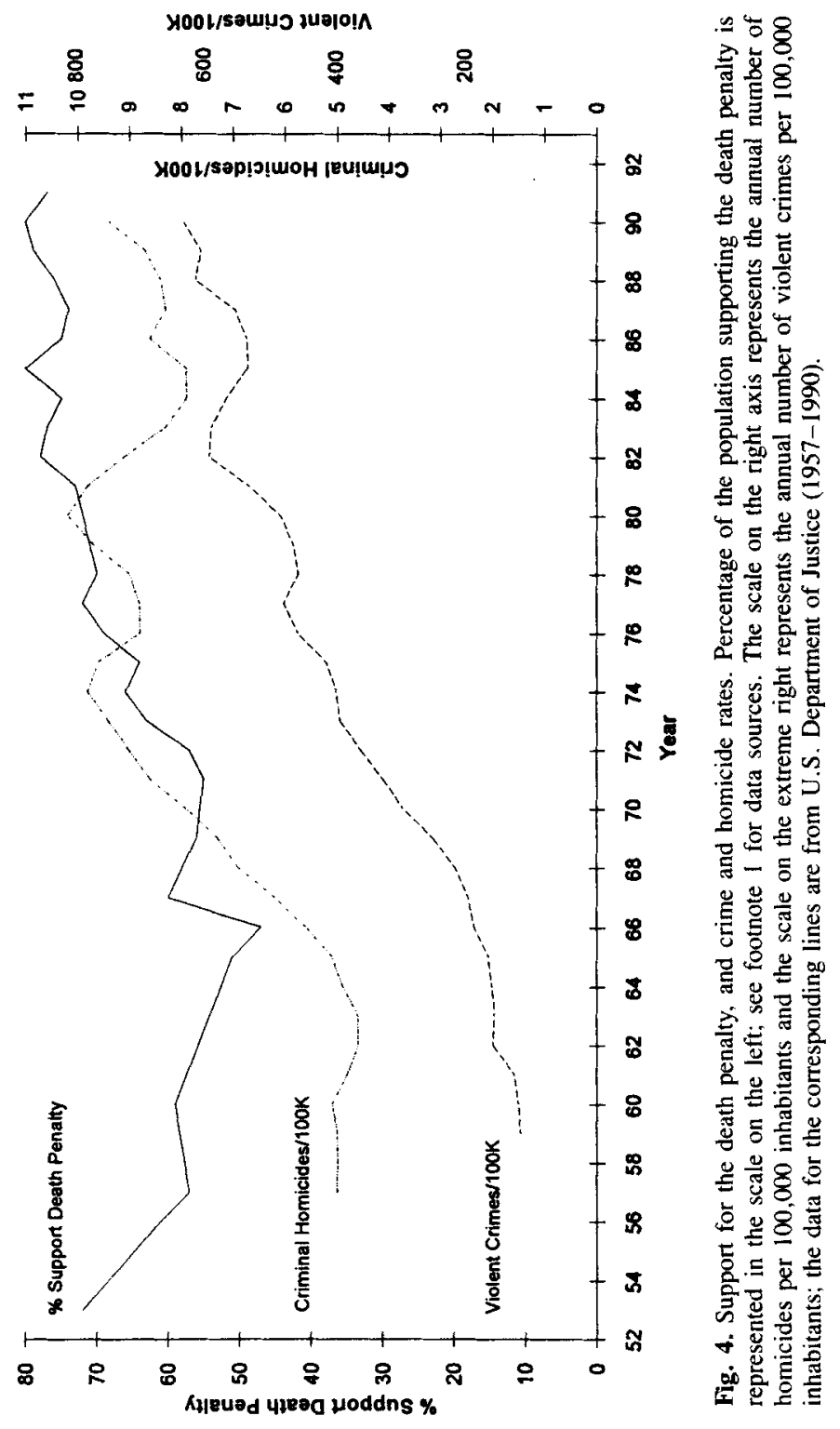


relationship between crime and death-penalty attitudes is bound to be more complicated. Public attitudes are not shaped by events themselves, but by public perception of those events. Thus it may be appropriate to assume a time lag between the reported crime rate and its impact on public opinion (Rankin, 1979), and it is likely that other factors-such as changes in media coverageexaggerate or dampen the effects of the underlying phenomena.

Despite these qualifications, the first two stages we have described seem clear enough: support for capital punishment declined when crime was low, and increased when it rose. What has happened since, and what to expect in the future, are different matters. For example, Fox et al. point out that the homicide rate peaked in 1980 at 10.2 (per 100,000 people), and declined to 8.4 by 1988 , while support, if anything, increased slightly (1991, p. 509, Fig. 3). This could mean that the decrease in homicide had not yet been noticed and absorbed; for example, Fox et al. cite data that, in $1989,82 \%$ of a national sample believed, erroneously, that crime was on the increase (Strasser, 1989). It could also mean that the decrease in homicide (assuming it was known) was too small or short term to matter. (And indeed, as Fig. 4 reveals, the homicide and crime rates have both increased again since 1987.) Finally, it is possible that this is not a symmetrical relationship, at least not in the short run. People who came to support the death penalty because of increasing crime may not change their minds back once the crime rate goes down. Under some circumstances, they might interpret the decrease as evidence that the death penalty, or other punitive measures, were successful.

Whatever the relationship between crime and support for the death penalty, it is not driven by personal experience. Many studies have shown that people who have been victimized themselves, or who fear for their personal safety, are no more likely to support the death penalty than those who have been more fortunate, or are less fearful (Fattah, 1979; Fox et al., 1991; Rankin, 1979; Smith, 1976; Stinchcombe et al., 1980; Taylor, Scheppele, \& Stinchcombe, 1979; Tyler \& Weber, 1982). On the other hand, a few studies have shown that concern about crime as a social issue is associated with support for capital punishment, if only weakly (Stinchcombe et al., 1980). If there is any one emotion that mediates between crime and support for the death penalty, it is probably frustration rather than fear. Year after year we live with high crime rates, we see graphic coverage of violence, we hear politicians promise to win the war against violence, against gangs, against drugs, against crime-but nothing changes. It is not hard to understand why many people support capital punishment even though they believe it does not deter crime and is not fair. The death penalty is concrete, it is forceful, and it is final (which nothing else seems to be); it is something, and being for it means that you insist that something be done.

In the 1970s and 1980s, most research on capital punishment in the United States was addressed to constitutional issues that were pending in the Supreme Court. This explains the interest in deterrence in the early 1970s: the constitu- 
tional significance of the deterrent effect of the death penalty was left open by the Furman decision in 1972. In 1976, however, in Gregg v. Georgia, the Court disposed of that issue by setting it aside, and interest in the topic diminished. Similarly, scholarly interest in death qualification was driven by the litigation leading up to the Supreme Court's definitive rejection of social science research in Lockhart v. McCree (1986), and interest in racial discrimination in capital punishment peaked in preparation for the Court's rejection of that claim in McCleskey v. Kemp (1987). To some extent, the same is true of research on attitudes toward capital punishment. Several of the best studies conducted in the 1970s were addressed to Justice Marshall's hypothesis in Furman that public support of the death penalty was caused by public ignorance, and several other studies since have also attempted to explain public attitudes in terms of the justifications for capital punishment that are described in Furman and Gregg: deterrence, retribution, incapacitation.

But the arena has shifted. On the one hand, the Supreme Court has made it plain that it will do little to regulate the use of the death penalty, let alone abolish it. On the other hand, the death penalty has become an increasingly prominent issue in electoral politics, and in that sphere the salient issues may be quite different. The best example by far is the Bush-Dukakis presidential race in 1988 .

During the Carter presidency, from 1976 to 1980 , the homicide and violent crime rates both rose sharply (see Fig. 4). President Carter supported the death penalty, but only in very limited circumstances; Governor Reagan-his opponent for reelection in 1980-was strongly for it. Most Americans, however, probably never knew this since "crime" was not an issue in that election. Four years later, when President Reagan ran against Walter Mondale, support for the death penalty had risen to about current levels. Mondale was against capital punishment under all circumstances, but again the issue barely surfaced. The 1988 presidential campaign started out the same way. In a national poll in May, respondents were asked which candidate "comes closer to your way of thinking" on the death penalty; $18 \%$ chose Dukakis, $21 \%$ chose Bush, and $61 \%$ said there was no difference or had no opinion (Gallup, 5/88). We can only conclude that Dukakis's position was not yet well known. In July, 15\% said Dukakis had "the best policy on the death penalty," $19 \%$ said Bush did, 14\% were unsure, and nearly half $-49 \%$ - had not heard enough to say (L.A. Times, 7/88). That did not last. In October, $71 \%$ of a national sample correctly chose Dukakis as the candidate who opposed the death penalty (12\% chose Bush; Gallup, $10 / 88$ ), and $63 \%$ of another national sample agreed that Dukakis "is too soft on law enforcement because he is against the death penalty and because he let a dangerous murderer go on furlough in Massachusetts, who then committed rape" (Harris, 10/88). By early November, respondents picked Bush over Dukakis as the candidate who would "do a better job of requiring the death penalty for crimes involving murder" by $61 \%$ to $24 \%$ (Yankelovitch, 11/88). After the election, $57 \%$ of Bush voters and $38 \%$ of Dukakis voters said the 
death penalty was "very important" to them in deciding who to vote for (Gallup, 11/88).

What happened between May and October is no secret. Starting in August, and accelerating in September after the national conventions were over, the Bush campaign drummed home the theme that is captured succinctly in the Harris poll question reproduced above: Dukakis is soft on crime because he is against the death penalty, and because he is responsible for the furlough of Willie Horton, the "dangerous murderer," who immediately committed a vicious rape. The attention this issue received seems to have created a short-term spike in general support for capital punishment. In April 1988, the GSS measured support at $71 \%$. In the heat of the campaign, two Gallup polls, in September and in October of 1988 , both found $79 \%$ support (an all-time record for "standard" death penalty questions), and a CBS/N.Y. Times poll in October registered $78 \%$ support. A second CBS/N.Y. Times poll taken two months after the election, in January 1989 , was back at $71 \%$ support, and the 1989 GSS, in April of that year, found $74 \%$ in favor of capital punishment.

There are two major lessons to be learned from the Willie Horton campaign. The first is that (for now at least) a candidate for president must support the death penalty. Governor Clinton made his support clear by presiding over two executions in Arkansas during the 1992 presidential campaign. As a result, the issue never surfaced in the presidential debates, in Republican campaign ads, or for that matter, in the national opinion polls-and Clinton won. Criminal justice in the United States is primarily a state and local function, and the federal death penalty in particular is a miniscule part of the nation's capital punishment system. Nonetheless, it may be a long time before anyone who opposes the death penalty is considered eligible for a major party nomination. The death penalty was not always so powerful a political issue. In 1978 Governor Jerry Brown, a life-long opponent of capital punishment, won reelection in California on the same ballot on which $72 \%$ of the electorate voted for a death penalty referendum, despite the fact that he had vetoed death penalty legislation just the year before (Poulos, 1990). By 1990, the California Democratic gubernatorial primary seemed to have become a contest over which candidate could be counted on to put more people to death (Gross, 1993).

The second lesson is that capital punishment, like violence and crime in general, is racially charged. It is no coincidence that Willie Horton is Black, or that the Bush campaign did everything humanly possible to make sure that every American voter got to see his picture.

\section{Some Future Directions}

Attitudes about capital punishment cannot be explained once and for all. Their meaning changes as the political climate changes, as the world changes, 
and as the media change people's perceptions of the world. New avenues of research are suggested.

The Willie Horton episode epitomizes the importance of studying racial factors. To what extent do attitudes toward the death penalty draw strength from the increasing association of race and crime in White people's minds? Not entirely, to be sure: the most horrifying criminals--Dahmer, Gacy, Bundy-are White, but these are the crazies, separate from people's perceptions of routine out-of-control violence in our cities. The relations between attitudes toward Blacks, crime, and the death penalty have not been explored in any depth. A second, equally interesting and even more neglected topic is Black Americans' attitudes toward capital punishment. Always more opposed than Whites, always more conscious of its discriminatory application, Blacks nonetheless are now more likely to favor the death penalty than to oppose it. It is very unlikely that the dynamics of Black attitudes are the same as those of the Whites, but there is no research on the topic.

Bowers' (1993) finding that people prefer guaranteed life imprisonment to the death penalty also raises new questions. In his research, the motives of incapacitation and retribution are inextricably confounded. If people were satisfied that a murderer could never commit another crime, would that be enough, or must he also suffer? What would people say if asked, "Would you rather Willie Horton was sentenced for life to a pleasant but utterly secure prison in Tahiti, with no possibility of ever returning to society, or would you rather he was sentenced to a vicious overcrowded maximum security prison for 30 years?" We have not moved far in untangling utilitarian and emotional bases for death penalty attitudes.

People's feelings about the death penalty are intense, yet we still have done very little to explore the underlying emotions. Research suggests that fear is not the driving emotion. Future research should focus on other emotions, particularly frustration and anger. Anger is the most positive of the negative emotions, because it is the only one that confers a sense of power (Ellsworth \& Smith, 1988; Roseman, 1984). When politicians argue, angrily, for the death penalty, they may communicate that they are in control, and at the same time arouse a satisfying sense of outrage and power in the voter. This is, of course speculation; the emotional dynamics of death penalty attitudes may be quite different. But there is no doubt that emotions play a role, and so far there has been little effort to understand that role.

\section{References}

Bohm, R. M. (1991). American death penalty opinion, 1936-1986: A critical examination of the Gallup polls. In R. M. Bohm (Ed.), The death penalty in America: Current research (pp. 113-145). Highland Heights, KY, and Cincinnati, OH: ACJS/Anderson. 
Bowers, W. J. (1993). Capital punishment and contemporary values: People's misgivings and the Court's misperception. Law and Society Review, 27, 157-175.

Bowers, W. J., \& Vandiver, M. (1991a). New Yorkers want an alternative to the death penalty: Executive summary of a New York State survey. Boston: Criminal Justice Research Center, Northeastern University.

Bowers, W. J., \& Vandiver, M. (1991b). Nebraskans want an alternative to the death penalty: Executive summary of Nebraska State Survey. Boston: Criminal Justice Research Center, Northeastern University.

California v. Ramos, 463 U.S. 992 (1982).

Cook, P. J., \& Slawson, D. B. (1993). The costs of processing murder cases in North Carolina. Terry Sanford Institute of Public Policy, Duke University.

Costanzo, S., \& Costanzo, M. (1994). Life or death decisions: An analysis of capital jury decision making under the special issues sentencing framework. Law and Human Behavior, 18, 151170.

Dieter, R. C. (1992). Millions misspent: What politicians don't say about the high costs of the death penalty. Washington, DC: The Death Penalty Information Center.

Dieter, R. C. (1993). Sentencing for life: Americans embrace alternatives to the death penalty. Washington, DC: The Death Penalty Information Center.

Doob, A. N., \& Roberts, J. (1984). Social psychology, social attitudes, and attitudes toward sentencing. Canadian Journal of Behavioural Science, 16, 269-280.

Ellsworth, P. C. (1978, November). Attitudes toward capital punishment: From application to theory. Paper presented at the Society of Experimental Social Psychology Symposium on Psychology and Law, Stanford, CA.

Ellsworth, P. C. (1988). Unpleasant facts: The Supreme Court's response to empirical research on the death penalty. In K. C. Haas \& J. Inciardi (Eds.), Adjudicating death: Moral and legal perspectives on capital punishment (pp. 177-221). Beverley Hills, CA: Sage.

Ellsworth, P. C., \& Ross, L. (1983, January). Public opinion and capital punishment: A close examination of the views of abolitionists and retentionists. Crime and Delinquency, pp. 116169.

Ellsworth, P. C., \& Smith, C. (1988). From appraisal to emotion: Differences among unpleasant feelings. Motivation and Emotion, 12, 271-302.

Erskine, H. (1970). The polls: Capital punishment. Public Opinion Quarterly, 34, 290-307.

Fattah, E. A. (1979). Perceptions of violence, concern about crime, fear of victimization and attitudes to the death penalty. Canadian Journal of Criminology, 21, 22-38.

Fein, S., \& Lord C. G. (1987). Concrete prototypes for abstract attitudes: The case of capital punishment. Paper presented at the 59th annual meeting of the Midwestern Psychological Association, Chicago.

Fox, J. A., Radelet, M. L., \& Bonsteel, J. L. (1991). Death penalty opinion in the post-Furman years. New York University Review of Law and Social Change, 28, 499-528.

Furman v. Georgia, 408 U.S. 238 (1972).

Gallup Poll News Service. (1991). 56, no. 8a.

Gorecki, J. (1983). Capital punishment: Criminal law and social evolution. New York: Columbia University Press.

Gregg v. Georgia, 428 U.S. 153 (1976).

Gross, S. R. (1993). The romance of revenge: Capital punishment in America. Studies in Law, Politics and Society, 13, 71-104.

Haney, C., Hurtado, A., \& Vega, L. (1993). Enlightened by a humane justice: Public opinion and the death penalty in California. Unpublished manuscript, University of Califomia, Santa Cruz.

Harris, P. W. (1986). Oversimplification and error in public opinion surveys on capital punishment Justice Quarterly, 3, 429-455.

Kinder, D. R. (in press). Reason and emotion in American political life. In R. Schank \& E. Langer (Eds.), Beliefs, reasoning, and decision making (pp. 277-314). Hillsdale, N.J.: Erlbaum.

Lockhart v. McCree, 476 U.S. 162 (1986). 
Lord, C. G., Ross, L., \& Lepper, M. R. (1979). Biased assimilation and attitude polarization: The effects of prior theories on subsequently considered evidence. Journal of Personality and Social Psychology, 37, 2098-2109.

McCleskey v. Kemp, 481 U.S. 279 (1987).

Nisbett, R. E., \& Wilson, T. (1977). Telling more than we can know: Verbal reports on mental processes. Psychological Review, 84, 231-251.

Page, B. I., \& Shapiro, R. Y. (1992). The rational public. Chicago: Chicago University Press.

Penry v. Lynaugh, 492 U.S. 302 (1989).

Poulos, J. W. (1990). Capital punishment, the legal process, and the emergence of the Lucas Court in California. University of California at Davis Law Review, 23, 157-332.

Radelet, M. L., Bedau, H. A., \& Putnam, C. E. (1992). In spite of innocence. Boston: Northeastern University Press.

Rankin, J. (1979). Changing attitudes towards capital punishment. Social Forces, 58, 194211.

Rapaport, R. (1991). The death penalty and gender discrimination. Law \& Society Review, 25, 367383.

Roberts, J. V. (1984). Public opinion and capital punishment-The effects of attitudes upon memory. Canadian Journal of Criminology, 26, 283-291.

Roberts v. Louisiana, 428 U.S. 325 (1976).

Roseman, I. (1984). Cognitive determinants of emotions: A structural theory. In P. Shaver (Ed.), Review of personality and social psychology: Vol. 5. Emotions, relationships, and health (pp. 11-36). Beverly Hills, CA: Sage.

Sarat, A., \& Vidmar, N. (1976), Public opinion, the death penalty, and the eighth amendment: Testing the Marshall hypothesis. Wisconsin Law Review, 17, 171-206.

Schuman, H., \& Presser, S. (1981). Questions and answers in attitude surveys, San Diego, CA: Academic Press.

Smith, T. W. (1976). A trend analysis of attitudes towards capital punishment, 1936-1974. In J. E. Davis (Ed.), Studies of social change since 1948 (Vol II). Chicago: NORC.

Stinchcombe, A., Adams, R., Heimer, C., Scheppele, K., Smith, T., \& Taylor, D. (1980). Crime and punishment: Changing attitudes in America. San Francisco: Jossey-Bass.

Strasser, F. (1989). One nation, under seige. National Law Journal, S2-S15.

Taylor, D. G., Scheppele, K. L., \& Stinchcombe, A. L. (1979). Salience of crime and support for harsher criminal sanctions. Social Problems, 26, 413-424.

Thomas, C. W. (1977). Eighth amendment challenges to the death penalty: The relevance of informed public opinion. Vanderbilt Law Review, 30, 1005-1030.

Thomas, C. W., \& Foster, S. C. (1975). A sociological perspective on public support for capital punishment. American Journal of Orthopsychiatry, 45, 641-657.

Tyler, T., \& Weber, R. (1982). Support for the death penalty: Instrumental response to crime, or symbolic attitude? Law and Society Review, 17, 21-45.

U.S. Department of Justice. (1957-1990). Crime in the United States, Uniform Crime Reports. Washington, DC.: Government Printing Office.

Vidmar, N. (1974). Retributive and utilitarian motives and other correlates of Canadian attitudes towards the death penalty. The Canadian Psychologist, 15, 337-356.

Vidmar, N., \& Ellsworth, P. C. (1974). Public opinion and the death penalty. Stanford Law Review, $26,1245-1270$.

Wallace, D. H. (1989). Bloodbath and brutalization: Public opinion and the death penalty. Journal of Crime and Justice, 12, 51-77.

Warr, M., \& Stafford, M. (1984). Public goals of punishment and support for the death penalty. Journal of Research in Crime and Delinquency, 21, 95-111.

Woodson v. North Carolina, 428 U.S. 280 (1976).

Zeisel, H., \& Gallup, A. M. (1989). Death penalty sentiment in the United States. Journal of Quantitative Criminology, 5, 285-296.

Zimring, F. E., \& Hawkins, G. (1986). Capital punishment and the American agenda. Cambridge: Cambridge University Press. 
Appendix. Surveys on General Death Penalty Attitudes

\begin{tabular}{|c|c|c|c|c|c|c|}
\hline Date & Organization & Q. Code & $N$ & $\%$ Favor & \% Oppose & \% Don't Know \\
\hline \multicolumn{7}{|c|}{ "Standard" Questions } \\
\hline Dec-36 & GALLUP & 01 & 1500 & 61 & 39 & \\
\hline Dec-37 & GALLUP & 02 & 1500 & 60 & 33 & 7 \\
\hline Nov-53 & GALLUP & 03 & 1498 & 64 & 25 & 11 \\
\hline Apr-56 & GALLUP & 03 & 2000 & 53 & 34 & 13 \\
\hline Sep-57 & GALLUP & 03 & 1528 & 47 & 34 & 18 \\
\hline Mar-60 & GALLUP & 03 & 1535 & 53 & 36 & 11 \\
\hline Jan-65 & GALLUP & 03 & 2435 & 45 & 43 & 12 \\
\hline May-66 & GALLUP & 03 & 1523 & 42 & 47 & 11 \\
\hline Jun-67 & GALLUP & 03 & 1518 & 56 & 36 & 8 \\
\hline $\operatorname{Jan}-69$ & GALLUP & 03 & 1503 & 51 & 40 & 9 \\
\hline Nov-71 & GALLUP & 03 & 1558 & 49 & 40 & 11 \\
\hline Mar-72 & GALLUP & 03 & 1513 & 50 & 42 & 9 \\
\hline Apr-72 & NORC & 04 & 1613 & 53 & 39 & 8 \\
\hline Nov-72 & GALLUP & 03 & 1462 & 57 & 32 & 11 \\
\hline Apr-73 & HARRIS & 05 & 1537 & 59 & 31 & 10 \\
\hline Apr-73 & NORC & 04 & 1504 & 60 & 35 & 5 \\
\hline Apr-74 & NORC & 04 & 1484 & 63 & 32 & 5 \\
\hline Apr-75 & NORC & 04 & 1490 & 60 & 33 & 6 \\
\hline Apr-76 & NORC & 04 & 1499 & 66 & 30 & 5 \\
\hline Apr-76 & GALLUP & 03 & 1540 & 66 & 26 & 7 \\
\hline Dec-76 & HARRIS & 05 & 1459 & 67 & 25 & 8 \\
\hline Apr-77 & NORC & 04 & 1530 & 67 & 26 & 6 \\
\hline Mar-78 & GALLUP & 03 & 1560 & 62 & 27 & 11 \\
\hline Apr-78 & NORC & 04 & 1532 & 66 & 28 & 6 \\
\hline Nov-78 & $\mathrm{NBC} / \mathrm{AP}$ & 04 & 1600 & 66 & 25 & 9 \\
\hline Jul-79 & $\mathrm{NBC} / \mathrm{AP}$ & 04 & 1599 & 65 & 27 & 8 \\
\hline Apr -80 & NORC & 04 & 1468 & 67 & 27 & 6 \\
\hline Nov-80 & LAT & 06 & 1829 & 62 & 29 & 9 \\
\hline Jan-81 & GALLUP & 07 & 1030 & 65 & 24 & 11 \\
\hline Feb-81 & GALLUP & 03 & 1609 & 66 & 25 & 9 \\
\hline May-81 & $\mathrm{ABC} /$ WASH & 03 & 1533 & 73 & 20 & 8 \\
\hline Apr-82 & NORC & 04 & 1506 & 74 & 21 & 6 \\
\hline Jun-82 & $\mathrm{NBC} / \mathrm{AP}$ & 04 & 1597 & 71 & 20 & 9 \\
\hline Dec-82 & $\mathrm{ABC}$ & 03 & 2464 & 76 & 19 & 5 \\
\hline Jan-83 & HARRIS & 05 & 1254 & 68 & 27 & 5 \\
\hline Apr-83 & NORC & 04 & 1599 & 73 & 22 & 5 \\
\hline Apr-84 & NORC & 04 & 1473 & 70 & 24 & 6 \\
\hline $\operatorname{Jan}-85$ & GALLUP & 03 & 1523 & 72 & 20 & 8 \\
\hline Apr-85 & NORC & 04 & 1534 & 76 & 19 & 5 \\
\hline Nov-85 & GALLUP & 04 & 1008 & 75 & 17 & 8 \\
\hline Apr-86 & NORC & 04 & 1470 & 71 & 24 & 5 \\
\hline Apr-87 & NORC & 04 & 1466 & 70 & 24 & 6 \\
\hline Apr-88 & NORC & 04 & 1481 & 71 & 22 & 7 \\
\hline Sep-88 & GALLUP & 04 & 1001 & 79 & 16 & 5 \\
\hline Oct-88 & GALLUP & 04 & 1001 & 79 & 16 & 5 \\
\hline Oct- 88 & CBS/NYT & 04 & 1518 & 78 & 14 & 8 \\
\hline Jan-89 & CBS/NYT & 04 & 1533 & 71 & 20 & 9 \\
\hline Apr-89 & NORC & 04 & 1537 & 74 & 20 & 6 \\
\hline Jun-89 & YANKCS & 08 & 504 & 75 & 17 & 8 \\
\hline
\end{tabular}


Appendix. (Continued)

\begin{tabular}{|c|c|c|c|c|c|c|}
\hline Date & Organization & Q. Code & $N$ & \% Favor & $\%$ Oppose & \% Don't Know \\
\hline \multicolumn{7}{|c|}{ "Standard" Questions (continued) } \\
\hline Apr-90 & NORC & 04 & 1372 & 75 & 19 & 6 \\
\hline Apr -90 & CBS/NYT & 04 & 1515 & 72 & 20 & 8 \\
\hline Jul-90 & $\mathrm{NBC} / \mathrm{WSJ}$ & 09 & 1555 & 71 & 20 & 9 \\
\hline Aug-90 & CBS/NYT & 04 & 1422 & 76 & 15 & 9 \\
\hline Apr-91 & NORC & 04 & 1517 & 72 & 22 & 6 \\
\hline May-91 & $\mathrm{NBC} / \mathrm{WSJ}$ & 09 & 1508 & 71 & 18 & 11 \\
\hline Jun-91 & GALLUP & 03 & 990 & 76 & 18 & 6 \\
\hline Nov-91 & GALLUP & 10 & 1011 & 73 & 21 & 6 \\
\hline Apr-92 & ABC/WASH & 04 & 1003 & 75 & 19 & 6 \\
\hline May-92 & $\mathrm{NBC} / \mathrm{WSJ}$ & 09 & 1118 & 69 & 24 & 7 \\
\hline \multicolumn{7}{|c|}{ Variations } \\
\hline Oct-64 & NORC & 11 & 1975 & 51 & 43 & 6 \\
\hline Apr-73 & HARRIS & 12 & 1537 & 81 & 16 & 3 \\
\hline Oct-74 & GALLUP & 13 & 1595 & 60 & 34 & 6 \\
\hline Dec-76 & HARRIS & 12 & 1459 & 84 & 13 & 3 \\
\hline Mar-77 & ROPER & 4 & 2001 & 71 & 22 & 7 \\
\hline Jul-77 & CBS/NYT & 15 & 1447 & 73 & 22 & 6 \\
\hline Jan-78 & ROPER & 16 & 2002 & 70 & 18 & 12 \\
\hline Aug-80 & GALLUP & 17 & 1600 & 53 & 42 & \\
\hline Sep-80 & GALLUP & 17 & 1602 & 56 & 44 & \\
\hline Jan-81 & ROPER & 16 & 2000 & 70 & 16 & 14 \\
\hline Jan-81 & YANK & 18 & 1219 & 68 & 23 & 9 \\
\hline May-81 & YANK & 19 & 1221 & 73 & 23 & 4 \\
\hline Sep-81 & YANK & 19 & 1222 & 73 & 21 & 6 \\
\hline Dec-81 & GALLUP & 17 & 1483 & 56 & 41 & \\
\hline Sep-82 & GALLUP & 20 & 1486 & 72 & 28 & \\
\hline Dec-82 & YANK & 19 & 1019 & 73 & 22 & 6 \\
\hline Jan-83 & HARRIS & 12 & 1254 & 87 & 11 & 2 \\
\hline Sep-83 & YANK & 21 & 1016 & 70 & 23 & 7 \\
\hline Dec-83 & YANK & 21 & 1000 & 69 & 22 & 9 \\
\hline Jan-84 & ROPER & 16 & 2000 & 68 & 18 & 14 \\
\hline Jun-84 & AP/MGEN & 22 & 1243 & 69 & 19 & 11 \\
\hline Sep-84 & YANK & 21 & 1023 & 74 & 18 & 8 \\
\hline Jul-85 & GALLUP & 17 & 2104 & 60 & 36 & 4 \\
\hline Jul-85 & YANK & 19 & 1013 & 75 & 20 & 5 \\
\hline Nov-86 & AP/MGEN & 23 & 1251 & 85 & 11 & 4 \\
\hline Jul-88 & CBS/NYT & 24 & 1177 & 71 & 21 & 8 \\
\hline Apr-89 & CBS/NYT & 24 & 1412 & 75 & 18 & 7 \\
\hline Dec-91 & NBC/WSJ & 25 & 1004 & 76 & 20 & 4 \\
\hline \multicolumn{7}{|c|}{ Scale-Answer Questions } \\
\hline Apr-81 & LAT & 26 & 1406 & 72 & 23 & 5 \\
\hline Feb-85 & LAT & 27 & 2993 & 75 & 17 & 8 \\
\hline Jan-86 & GALLUP & 28 & 1570 & 70 & 22 & 8 \\
\hline Jul-86 & LAT & 29 & 2405 & 74 & 16 & 10 \\
\hline May-87 & GALLUP & 30 & 4244 & 72 & 23 & 5 \\
\hline Mar-89 & LAT & 29 & 3583 & 69 & 18 & 13 \\
\hline
\end{tabular}


Appendix. (Continued)

Sources and questions used in appendix

\begin{tabular}{ll}
\hline GALLUP & Gallup Organization \\
NORC & National Opinion Research Center \\
HARRIS & Louis Harris and Associates \\
NBC/AP & NBC News/Associated Press \\
LAT & Los Angeles Times \\
ABC/WASH & ABC News/Washington Post \\
ABC & ABC News \\
CBS/NYT & CBS News/New York Times \\
YANCKS & Yankelovich Clancy Shulman \\
NBC/WSJ & NBC News/Wall Street Journal \\
ROPER & Roper Organization \\
YANK & Yankelovich, Skelly and White \\
AP/MGEN & Associated Press/Media General \\
\hline
\end{tabular}

Question Wordings

"Standard" Questions

\section{Code no.}

01 Do you believe in the death penalty for murder?

Do you favor or oppose capital punishment for murder?

Are you in favor of the death penalty for persons convicted of murder?

Do you favor or oppose the death penalty for persons convicted of murder?

Do you believe in capital punishment/death penalty or are you opposed to it?

Do you approve or disapprove of the death penalty?

Are you in favor of or opposed to the death penalty for persons convicted of murder?

Do you, in general, favor or oppose the death penalty for individuals convicted of serious crimes, such as murder?

Do you favor or oppose the death penalty?

I'm going to read you some proposals that are being discussed around the country today. As I read each proposal, please tell me whether you would favor or oppose it. . . A death penalty for persons convicted of murder.

\section{Variations}

Do you think that having a death penalty for the worst crimes is a good idea or are you against the death penalty?

Do you feel that all persons convicted of first degree murder should get the death penalty, that no one convicted of first degree murder should get the death penalty, or do you feel that whether or not someone convicted of first degree murder gets the death penalty should depend on the circumstances of the case and the character of the person?

Suppose that on election day, November 5 (1974), you could vote on these key issues. Please tell me how you would vote on each, remembering that you should try to vote for or against each proposition just as you would in a regular referendum. Proposition 1: Death Penalty. . . I I (favor/oppose) the death penalty for persons convicted of murder.

Opinions differ as to whether there should be a death penalty for certain very serious crimes, or whether there should not be a death penalty for any crime, no matter how serious it is. How do you feel-are you in favor of the death penalty for certain crimes, or opposed to the death penalty under any circumstances? 
Appendix. (Continued)

Question Wordings

Variations

Code no.

15

16
Are there any crimes for which you think the death penalty is justified?

Frequently on any controversial issue there is no clear cut side that people take, and also frequently solutions on controversial issues are worked out by compromise.

But I'm going to name some different things, and for each one would you tell me whether on balance you would be more in favor of it, or more opposed to it? Imposing the death penalty on those convicted of serious crimes such as murder, kidnapping, etc.

[Here are] [This card lists] various proposals being discussed in this country today. Would you tell me whether you generally favor or generally oppose each of these proposals? . . . A mandatory death penalty for anyone convicted of murder.

Do you personally hope that the Reagan administration will or will not work to see that: The death penalty is reinstituted?

Now I'd like to know how you feel about a number of important issues that face the country. Do you favor or oppose: . . . Wider use of the death penalty for certain crimes such as hijacking or the killing of a police officer?

Suppose that on Election Day, November 2 (1982), you could vote on key issues as well as candidates. Please tell me how you would vote on each of these propositions. . . . I (favor/oppose) the death penalty for persons convicted of murder.

Do you favor or oppose bringing back the death penalty?

Various proposals have been made as possible solutions to the increased crime rate. Please tell me whether you personally favor or oppose the following as measures to reduce the crime rate. Death penalty.

In general, do you feel the death penalty should be allowed in all murder cases, only in certain murder cases, or should there be no death penalty at all?

Are there circumstances under which you think the death penalty is justified?

Let me read you a number of different proposals people have made about how to change the U.S. (United States) Constitution. For each proposal, please tell me whether you would favor or oppose this change in the Constitution. Amending the Constitution to outlaw the death penalty as cruel and unusual punishment. . . Would you favor or oppose this change in the Constitution? "Oppose" coded as "favor death penalty"]

\section{Scale-answer questions}

Do you approve or disapprove of the death penalty? Do you feel strongly about that, or not so strongly?

Generally speaking, are you in favor of the death penalty for persons convicted of murder, or are you opposed to that-or haven't you heard enough about that to say?

Do you favor or oppose the death penalty for persons convicted of murder? (If "Favor" or "Oppose," ask:) How strongly do you (favor/oppose) the death penalty for persons convicted of murder-very strongly or not too strongly?

Generally speaking, are you in favor of the death penalty for persons convicted of murder, or are you opposed to that- or haven't you heard enough about that to say? (If in favor or opposed) Is that (in favor/opposed) strongly or (in favor/ opposed) somewhat?

The following is a list of some programs and proposals that are being discussed in this country today. For each one, please tell me whether you strongly favor, favor, oppose, or strongly oppose. . . . A mandatory death penalty for anyone convicted of premeditated murder. 
PHOEBE C. ELLSWORTH is a professor of psychology and a professor of law at the University of Michigan. She received her Ph.D. in psychology from Stanford University in 1970, taught at Yale from 1971 to 1981, at Stanford from 1981 to 1987 , and has been at Michigan ever since. Her areas of specialty are law and psychology, and basic research on emotions. Before this article she has always kept the two quite separate.

SAMUEL R. GROSS is a professor of law at the University of Michigan. He received his J.D. from the University of California at Berkeley in 1973. He practiced law from 1974 until 1982, taught at Stanford University from 1982 to 1987, and has been at Michigan since 1987. His areas of specialty are evidence law, the determinants of trial and settlement, the use of social science in litigation, and capital punishment. 